\title{
Effect of driving resistances on energy demand and exhaust emission in motor vehicles
}

ARTICLE INFO

Received: 15 July 2021

Revised: 6 October

Accepted: 7 October 2021

Available online: 29 October 2021

Among the fundamental factors affecting the emissions of internal combustion engines is the resistance to motion acting on the car. This is an important factor to be taken into account when testing cars in conditions simulated on a chassis dynamometer. The dependence of the driving resistance function on vehicle speed is determined on the basis of various methods, the most frequently used of which is the so-called alternative method specified in procedures for the type approval of motor vehicles with respect to the emission of pollutants in exhaust gases. The values adopted in accordance with the alternative method differ from the actual resistance acting on the car in road conditions. This is one of the reasons why the emission of pollutants and the fuel consumption of an engine in real road conditions differs from the values given by the car manufacturer, including the emission limits specified in the standards. This paper presents an evaluation of the influence of driving resistance on the energy demand and emission of pollutants in the exhaust gases by sample passenger car with SI engine fuelled by petrol and $L P G$.

Key words: driving resistance, exhaust emission, vehicles, emission tests, energy demand

This is an open access article under the CC BY license (http://creativecommons.org/licenses/BY/4.0/)

\section{Introduction}

The emission of pollutants in vehicle exhaust gases is a fundamental problem related to vehicle operation. Increased population awareness exerts pressure on manufacturers manifesting itself in increasingly lower emission limits expressed in successive editions of vehicle type approval standards.

Tests of pollutant emissions in vehicle exhaust are carried out in laboratory driving cycles [4] and in tests conducted in real road conditions [9, 25, 27, 29, 30, 33]. The results of the actual emission tests are used in the studies conducted by the simulation method. [19]. Tests performed on a chassis dynamometer are characterized by high repeatability[17]. Tests on a chassis dynamometer, carried out as part of type approval tests, are intended to evaluate the emission of exhaust pollutants from vehicles and fuel (energy) consumption $[5,7,8,14,28,42]$. However, often the results of tests on exhaust emissions obtained on a chassis dynamometer turn out to be lower than in real driving emissions (RDE) road tests [10, 16, 22, 26, 32, 41].

During laboratory testing, the aim is to approximate as closely as possible the test conditions relating to vehicle drag on the road. This is very difficult due to many factors occurring in real traffic, such as ambient temperature, driver's driving style, road gradient and wind effects $[1,6,20$, $21,31,38,44]$. Additionally, the problem relates to the real-time representation of drag forces by the chassis dynamometer, which involves not only the basic resistance to motion, i.e., air and rolling, but also inertia resistance. The steady-state load values on the chassis dynamometer affect the results of exhaust emissions and fuel (energy) consumption $[15,24,35,39,40]$. The vehicle drag force, $F_{o}$, for a horizontal road is described by the equation:

$$
\mathrm{F}_{\mathrm{o}}=\mathrm{F}_{\mathrm{t}}+\mathrm{F}_{\mathrm{b}}+\mathrm{F}_{\mathrm{p}}[\mathrm{N}]
$$

where: $F_{t}$ - rolling resistance force $[N], F_{p}-$ drag force $[N]$, $\mathrm{F}_{\mathrm{b}}$ - inertia resistance force $[\mathrm{N}]$.

For tests on a chassis dynamometer, it is necessary to introduce the resistance force function, the so-called dynamometer characteristic curve, which includes the forces acting on the car in steady state motion on a horizontal road. These are the air and rolling resistance, which are usually expressed as a second-degree polynomial [2]:

$$
\mathrm{F}_{\mathrm{t}, \mathrm{p}}=\mathrm{F}_{\mathrm{t}}+\mathrm{F}_{\mathrm{p}}=\mathrm{m} \cdot \mathrm{g} \cdot \mathrm{f}_{\mathrm{o}} \cdot\left(1+5 \cdot 10^{-5} \cdot \mathrm{v}^{2}\right)+0.047 \cdot \mathrm{A} \cdot \mathrm{c}_{\mathrm{x}} \cdot \mathrm{v}^{2}
$$

where: $\mathrm{m}$ - weight of the car $[\mathrm{kg}], \mathrm{f}_{0}$ - rolling resistance coefficient for low travel speed close to zero, $\mathrm{g}$ - acceleration due to gravity $\left[\mathrm{m} / \mathrm{s}^{2}\right], \mathrm{v}-$ speed $[\mathrm{km} / \mathrm{h}], \mathrm{A}-$ frontal area of the car $\left[\mathrm{m}^{2}\right], \mathrm{c}_{\mathrm{x}}-$ aerodynamic drag coefficient in the longitudinal direction.

The inertia drag force is calculated from the formula:

$$
\mathrm{F}_{\mathrm{b}}=\mathrm{m} \cdot \delta \cdot \mathrm{a}[\mathrm{N}]
$$

where: $\delta$ - rotating mass factor, $\mathrm{a}-$ acceleration $\left[\mathrm{m} / \mathrm{s}^{2}\right]$.

The values of the motion resistance force functions as a function of travel speed are entered into the control software through coefficients determined by various methods $[6,12,13,23,24,35,43]$. Due to the fact that the dynamometer reproduces the resistances acting on the car in real conditions, the most advantageous method is the one based on road coast-down tests $[18,24,35]$, on the basis of which the values of coefficients of the equation $X_{0}, X_{1}$ and $X_{2}$ :

$$
\mathrm{F}_{\mathrm{t}, \mathrm{p}}=\mathrm{X}_{0}+\mathrm{X}_{1} \cdot \mathrm{v}+\mathrm{X}_{2} \cdot \mathrm{v}^{2}[\mathrm{~N}]
$$

With the vehicle manufacturer's consent, the so-called alternative method may be used, which consists in determining the brake load for absorbing the force $F_{c}$ of the resistance depending on the mass of the vehicle by selecting the coefficients $\mathrm{A}_{0}$ and $\mathrm{B}_{0}$ from the table of Regulations 
[43]. In this case, the motion resistance function is expressed by the formula:

$$
\mathrm{F}_{\mathrm{c}}=\mathrm{A}_{0}+\mathrm{B}_{0} \cdot \mathrm{v}^{2}[\mathrm{~N}]
$$

\section{Materials and methods}

The tests were carried out on an AVL-Zoellner ROADSIM 48" chassis dynamometer installed in a climatic chamber at the Automotive Ecology Centre of the Rzeszow University of Technology (Fig. 1). The basic technical data of AVL ROADSIM 48" Chassis Dynamometer are presented in Table 1. The tested vehicle was a passenger car equipped with an SI internal combustion engine. The basic technical data of the tested car are presented in Table 2. The tested car is representative of the average age of cars in Poland [37]. During the NEDC tests, the values of brake forces and power were recorded for two dynamometer settings using the AVL MMI software. The tests were carried out for the resistance force $\mathrm{F}_{\mathrm{t}, \mathrm{p}}$ determined by the road coast-down test, and for the force determined by the alternative method. The values of the coefficients determined by the road coast-down test and by the alternative method are shown in Table 3. The characteristics of the theoretical changes of the calculated values of both forces as a function of the driving speed are shown in Fig. 2. Figure 3 shows an example of the changes in the recorded actual values of the resistance forces on the chassis dynamometer during the tests, including the inertia resistance. In addition, this graph shows the values of power and cumulative energy demand for example tests performed for the analyzed dynamometer settings. It can be seen that during the execution of the driving cycle, the actual values of speed and acceleration differ from the theoretical values of the cycle. This also affects the actual values of the motion resistance forces acting on the wheels of the car.

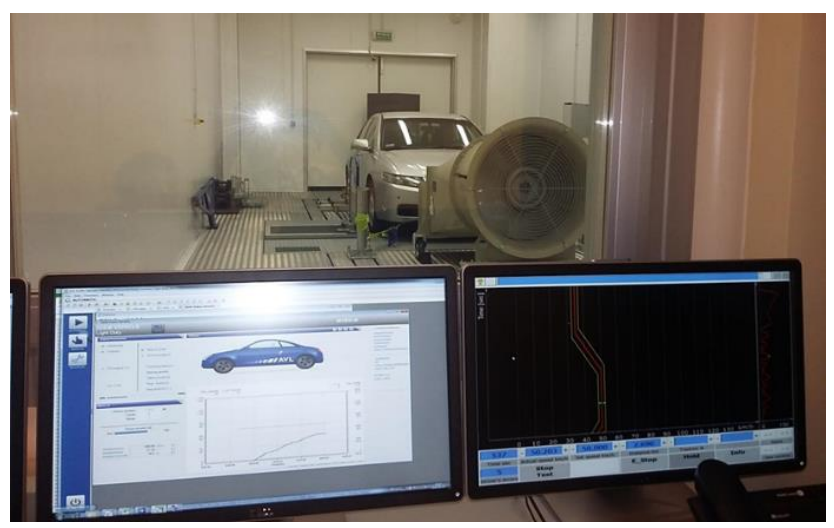

Fig. 1. View of the car on the test stand

Measurements of gaseous emissions: $\mathrm{CO}_{2}, \mathrm{CO}$, THC, $\mathrm{CH}_{4}, \mathrm{NMHC}$ and NOx were carried out using AVL AMA i60 system. Specification of accuracy of AMA i60 analyzers is presented in Table 4. Due to comparative tests carried out on cars fuelled with petrol and LPG, the tests were conducted from a hot start. In the case of cold start tests, with LPG powering, the initial phase (about $100 \mathrm{~s}$ ) started with petrol powering the engine [13]. For tests from hot start, before the test, the engine coolant temperature was $90 \pm 2^{\circ} \mathrm{C}$. In this case, switching to LPG fuel took place immediately after starting the engine. The tests were conducted at ambient temperature of $23 \pm 1{ }^{\circ} \mathrm{C}$.

Table 1. Basic technical data of AVL ROADSIM 48" Chassis Dynamometer [36]

\begin{tabular}{|l|c|}
\hline Parameter & Value \\
\hline Dimensions (Length/Width/Height) & $\begin{array}{c}3,600 \mathrm{~mm} / 1,600 \mathrm{~mm} / 1,300 \\
\mathrm{~mm}\end{array}$ \\
\hline Roller diameter & $1,219 \mathrm{~mm}$ \\
\hline Roller mass & $765 \mathrm{~kg}$ \\
\hline Rated power & $153 \mathrm{~kW}$ \\
\hline Instantaneous power & $258 \mathrm{~kW}$ \\
\hline Maximum speed & $200 \mathrm{~km} / \mathrm{h}$ \\
\hline Inertia simulation range & $454 \mathrm{~kg} \ldots 2,722 \mathrm{~kg}$ \\
\hline $\begin{array}{l}\text { Maximum continuous tractive } \\
\text { force }\end{array}$ & $5,987 \mathrm{~N}$ \\
\hline $\begin{array}{l}\text { Maximum instantaneous tractive } \\
\text { force }\end{array}$ & $10,096 \mathrm{~N}$ \\
\hline Tractive force measurement error & $\leq 0.1 \%$ \\
\hline Speed measurement error & $\leq 0.02 \mathrm{~km} / \mathrm{h}$ \\
\hline Distance measurement error & $0.001 \% / \mathrm{m}$ \\
\hline Maximum axle load & $2,000 \mathrm{~kg}$ \\
\hline
\end{tabular}

Table 2. Technical data of the vehicle

\begin{tabular}{|l|c|}
\hline Parameter & Value \\
\hline Length/Width/Height & $4,665 \mathrm{~mm} / 1,760 \mathrm{~mm} / 1,445 \mathrm{~mm}$ \\
\hline Wheelbase & $2,670 \mathrm{~mm}$ \\
\hline Weight & $1,430 \mathrm{~kg}$ \\
\hline Engine type & Petrol (gasoline) \\
\hline Fuel System & $1998 \mathrm{~cm}^{3}$ \\
\hline Engine displacement & $190 \mathrm{Nm} @ 6,000,500 \mathrm{rpm}$ \\
\hline Engine power & 4 \\
\hline Engine torque & 16 \\
\hline Number of cylinders & Front \\
\hline Number of valves & 5 \\
\hline Wheel drive & Multiont \\
\hline $\begin{array}{l}\text { Number of gears (manual } \\
\text { transmission) }\end{array}$ & $205 / 55 \mathrm{R} 16$ \\
\hline Tire size & $130,000 \mathrm{~km}$ \\
\hline Car mileage & Three-way catalytic converter \\
\hline $\begin{array}{l}\text { Exhaust purification } \\
\text { system }\end{array}$ & Euro 3 \\
\hline Emission standard & \\
\hline
\end{tabular}

Table 3. Coefficients of resistance

\begin{tabular}{|l|c|c|}
\hline Coefficient & Road method & Alternative method \\
\hline $\mathrm{X}_{0}[\mathrm{~N}]$ & 155.11 & - \\
\hline $\mathrm{X}_{1}[\mathrm{~N} /(\mathrm{km} / \mathrm{h})]$ & -0.3429 & - \\
\hline $\mathrm{X}_{2}\left[\mathrm{~N} /(\mathrm{km} / \mathrm{h})^{2}\right]$ & 0.0361 & - \\
\hline $\mathrm{A}_{0}[\mathrm{~N}]$ & - & 7.6 \\
\hline $\mathrm{B}_{0}\left[\mathrm{~N} /(\mathrm{km} / \mathrm{h})^{2}\right]$ & - & 0.0515 \\
\hline Equivalent inertia $[\mathrm{kg}]$ & 1590 & 1590 \\
\hline
\end{tabular}

Table 4. Specification of accuracy of AMA i60 analyzers [3]

\begin{tabular}{|c|c|c|c|c|}
\hline $\begin{array}{l}\text { Parameter } \backslash \\
\text { Analyzer }\end{array}$ & CLD i60 LD & FID i60 LCD & IRD i60 $\mathrm{CO}_{2 \mathrm{~L}}$ & IRD i60 L \\
\hline $\begin{array}{l}\text { Measured } \\
\text { components }\end{array}$ & $\mathrm{NO}$ and $\mathrm{NO}_{\mathrm{x}}$ & THC and $\mathrm{CH}_{4}$ & $\overline{\mathrm{CO}_{2}}$ & $\mathrm{CO}$ \\
\hline $\begin{array}{l}\text { Reproduci- } \\
\text { bility }\end{array}$ & $\begin{array}{l}\leq 0.5 \% \text { of } \\
\text { range full } \\
\text { scale }\end{array}$ & $\begin{array}{l}\leq 0.5 \% \text { of } \\
\text { range full } \\
\text { scale }\end{array}$ & $\begin{array}{l}\leq 0.5 \% \text { of } \\
\text { range full } \\
\text { scale }\end{array}$ & $\begin{array}{l}\leq 0.5 \% \text { of } \\
\text { range full } \\
\text { scale }\end{array}$ \\
\hline Linearity & $\begin{array}{c}\leq 2 \% \text { of } \\
\text { measured } \\
\text { value }(10- \\
100 \% \text { of range } \\
\text { full scale) } \\
\leq 1 \% \text { of range } \\
\text { full scale } \\
\text { whichever is } \\
\text { smaller }\end{array}$ & \begin{tabular}{|c|}
$\leq 2 \%$ of \\
measured \\
value $(10-$ \\
$100 \%$ of range \\
full scale) \\
$\leq 1 \%$ of range \\
full scale \\
whichever is \\
smaller
\end{tabular} & $\begin{array}{c}\leq 2 \% \text { of } \\
\text { measured } \\
\text { value }(10- \\
100 \% \text { of range } \\
\text { full scale) } \\
\leq 1 \% \text { of range } \\
\text { full scale } \\
\text { whichever is } \\
\text { smaller }\end{array}$ & $\begin{array}{c}\leq 2 \% \text { of } \\
\text { measured } \\
\text { value }(10- \\
100 \% \text { of range } \\
\text { full scale) } \\
\leq 1 \% \text { of range } \\
\text { full scale } \\
\text { whichever is } \\
\text { smaller }\end{array}$ \\
\hline
\end{tabular}




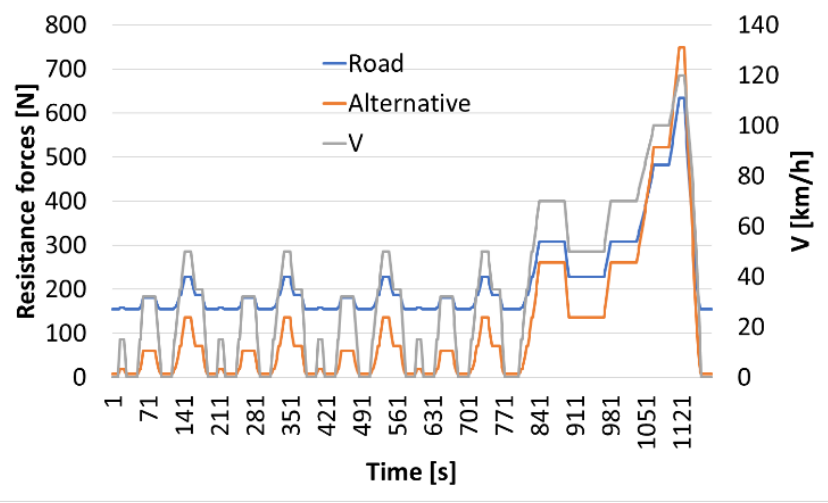

Fig. 2. Calculated resistance forces $F_{t, p}$ and $F_{c}$ for road and alternative methods

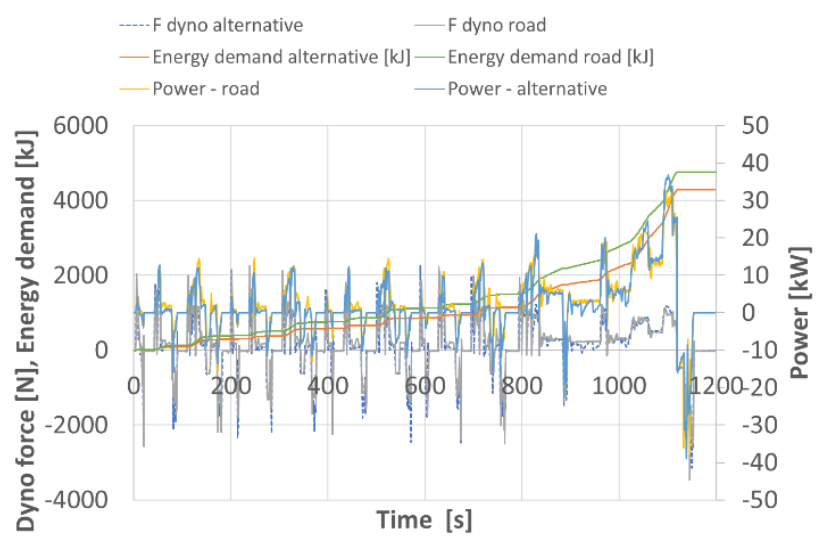

Fig. 3. Sample of measured dyno forces, dyno power and energy demand for road and alternative resistance functions

On the basis of performed tests of exhaust emissions, the EC energy consumption was calculated with the carbon balance method. The values of energy consumption for the gasoline fueling were determined from equation (6), while for the LPG fueling - from equation (7) [34]:

$\mathrm{EC}_{\text {Petrol }}=$

$\frac{0.1154}{3.6 \cdot \mathrm{LHV}_{\text {Petrol }}}\left(0.866 \cdot \mathrm{HC}+0.429 \cdot \mathrm{CO}+0.273 \cdot \mathrm{CO}_{2}\right)\left[\frac{\mathrm{kWh}}{100 \mathrm{~km}}\right]$

$\mathrm{EC}_{\mathrm{LPG}}=$

$\frac{0.1212}{3.6 \cdot \mathrm{LHV}_{\mathrm{LPG}}}\left(0.825 \cdot \mathrm{HC}+0.429 \cdot \mathrm{CO}+0.273 \cdot \mathrm{CO}_{2}\right)\left[\frac{\mathrm{kWh}}{100 \mathrm{~km}}\right]$

where: $\mathrm{HC}$ - hydrocarbons mass emission $[\mathrm{g} / \mathrm{km}], \mathrm{CO}-$ carbon monoxide mass emission $[\mathrm{g} / \mathrm{km}], \mathrm{CO}_{2}-$ carbon dioxide mass emission $[\mathrm{g} / \mathrm{km}], \mathrm{LHV}_{\text {Petrol }}$ - lower heating value of petrol $[\mathrm{MJ} / \mathrm{kg}], \mathrm{LHV}_{\mathrm{LPG}}$ - lower heating value of LPG $[\mathrm{MJ} / \mathrm{kg}]$.

Fuel economy values for petrol fuelling were determined from equation (8), while for LPG fuelling - from equation (9) [34]:

$$
\begin{aligned}
\mathrm{FE}_{\text {Petrol }} & =\frac{100 \cdot \rho_{\text {Petrol }}}{0.1154 \cdot\left(0.866 \cdot \mathrm{HC}+0.429 \cdot \mathrm{CO}+0.273 \cdot \mathrm{CO}_{2}\right)}\left[\frac{\mathrm{km}}{1}\right] \\
\mathrm{FE}_{\mathrm{LPG}} & =\frac{100 \cdot \rho_{\mathrm{LPG}}}{0.1212 \cdot\left(0.825 \cdot \mathrm{HC}+0.429 \cdot \mathrm{CO}+0.273 \cdot \mathrm{CO}_{2}\right)}\left[\frac{\mathrm{km}}{1}\right]
\end{aligned}
$$

where: HC - hydrocarbons mass emission factor $[\mathrm{g} / \mathrm{km}]$, $\mathrm{CO}$ - carbon monoxide mass emission factor $[\mathrm{g} / \mathrm{km}], \mathrm{CO}_{2}-$ carbon dioxide mass emission factor $[\mathrm{g} / \mathrm{km}], \rho_{\text {Petrol }}-$ petrol density $\left[\mathrm{kg} / \mathrm{dm}^{3}\right], \rho_{\mathrm{LPG}}-\mathrm{LPG}$ density $\left[\mathrm{kg} / \mathrm{dm}^{3}\right]$.

Then the theoretical values of motor efficiency were determined from equation (10):

$$
\eta_{\mathrm{o}, \mathrm{j}}=\frac{\mathrm{ER}_{\mathrm{j}}}{\mathrm{G}_{\mathrm{pal}, \mathrm{j}} \cdot \mathrm{LHV}_{\mathrm{pal}, \mathrm{k}} \cdot \eta_{\mathrm{un}}}
$$

where: $\eta_{o, j}$ - average overall engine efficiency in phase $\mathrm{j}$ (UDC, EUDC) and in the NEDC test, $\mathrm{G}_{\mathrm{pal}, \mathrm{j}}$ - engine mass fuel consumption in phase $\mathrm{j}$ (UDC, EUDC) and the NEDC test [kg], $\mathrm{LHV}_{\text {pal,k }}-$ lower calorific value of $\mathrm{k}_{\mathrm{th}}$ fuel $[\mathrm{kJ} / \mathrm{kg}$ ], $\mathrm{ER}_{\mathrm{j}}$ - total energy demand of car movement in phase $\mathrm{j}$ (UDC, EUDC) and for the NEDC test $[\mathrm{kJ}], \eta_{\mathrm{un}}-$ average efficiency of the car transmission system.

The value of energy consumption of traffic for individual sections of the test cycle was calculated according to equation (11):

$$
\mathrm{ER}_{\mathrm{j}}=\mathrm{F}_{\mathrm{oj}} \cdot \mathrm{s}_{\mathrm{j}}[\mathrm{J}]
$$

where: $\mathrm{ER}_{\mathrm{j}}$ - the energy demand of the car movement for the $\mathrm{j}$-th test phase $[\mathrm{J}], \mathrm{F}_{\mathrm{oj}}$ - resistance force in the car motion for the $j$-th test phase $[N], s_{j}$ - distance of the $j$-th test phase $[\mathrm{m}]$.

\section{Results and discussion}

The results of tests on the emission of the analysed pollutants in exhaust gases of the tested vehicle have been presented in Figs 4 to 15. The presented average values of emission factors for two test, for petrol and LPG fuels have been presented for two function of the traffic resistance forces, which were determined using the road method and the alternative method.

The influence of traffic resistance is particularly evident for $\mathrm{CO}_{2}$ emissions (Fig. 4 to 6). The values of $\mathrm{CO}_{2}$ emission factors are higher for tests with dynamometer load determined from road coast-down tests in relation to the load determined from the alternative method. In the case of the UDC phase (Fig. 4), the $\mathrm{CO}_{2}$ emission rate values for the gasoline-fueled road load were about $7 \%$ higher than the value obtained for the load according to the alternative method.

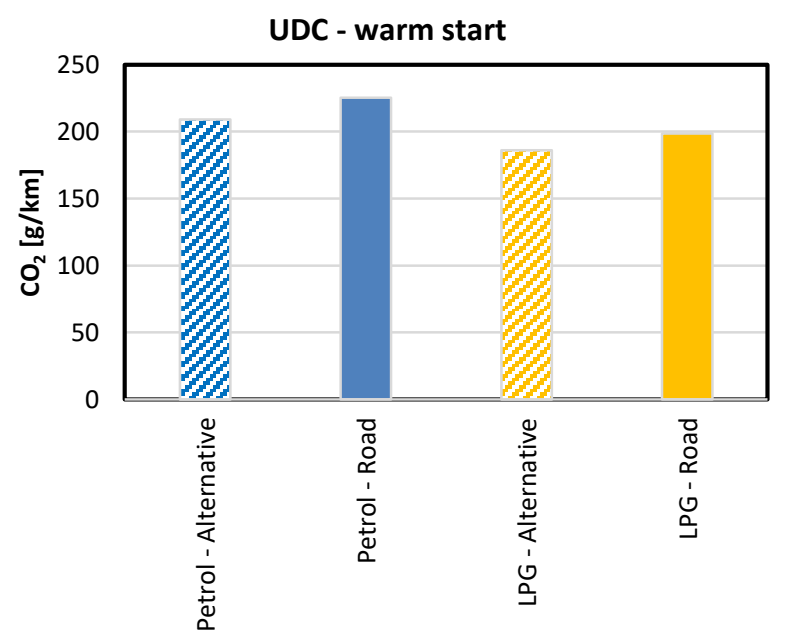

Fig. 4. Impact of resistance forces on $\mathrm{CO}_{2}$ emissions for UDC phase 
For LPG fueling, the difference was about $6 \%$. For the EUDC phase (Fig. 5), the difference of the $\mathrm{CO}_{2}$ emission factor was about $1 \%$, while for the whole test (Fig. 6) it was about $4 \%$ when powered by gasoline and LPG. For the remaining pollutants analyzed $\left(\mathrm{THC}, \mathrm{CO}, \mathrm{NO}_{\mathrm{x}}\right.$ ), no clear correlations were obtained between the dynamometer loading according to the established road and alternative methods on their emissions. In the case of gasoline fueling, the average THC emission for the road load was higher than for the alternative load (Fig. 7 and 9), while for LPG the relationship was the opposite. For the EUDC phase (Fig. 8), the average THC emissions for both tested fuels were higher for the dynamometer load by the alternative method than by the road method.

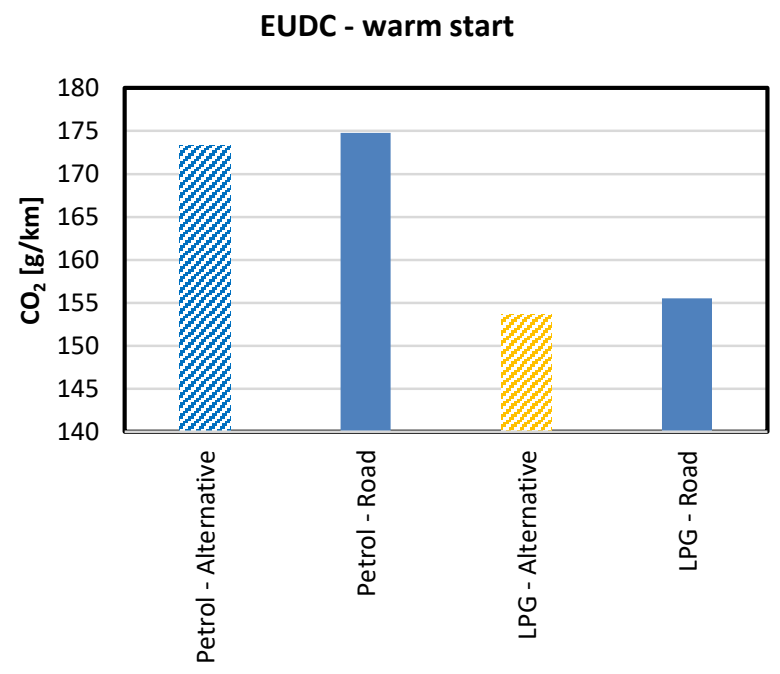

Fig. 5. Impact of resistance forces on $\mathrm{CO}_{2}$ emissions for EUDC phase

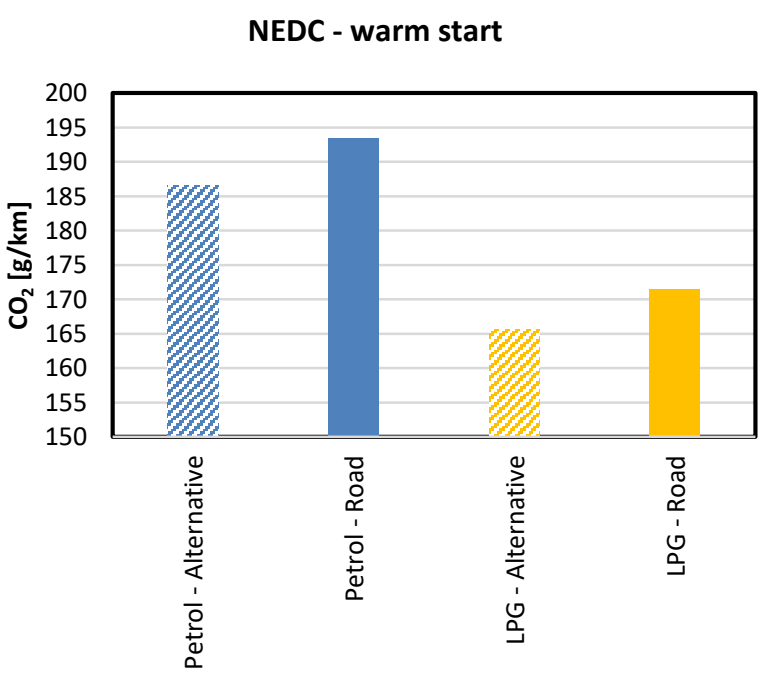

Fig. 6. Impact of resistance forces on $\mathrm{CO}_{2}$ emissions for NEDC tests

Similar relationships were obtained for CO (Fig. 10 to 12) and $\mathrm{NO}_{\mathrm{x}}$ emission rates (Fig. 13 to15). In the case of $\mathrm{CO}$ when fuelled with gasoline, higher emission factor values were obtained at the road load of the dynamometer (Fig. 10 to Fig. 12) than at the alternative load. When run- ning on LPG, the results were the opposite, i.e. higher $\mathrm{CO}$ emission index values were obtained for the alternative load, both for the urban (Fig. 10), extra-urban phase (Fig. 11) and the entire NEDC cycle (Fig. 12). As with THC, $\mathrm{NO}_{\mathrm{x}}$ emission rates from the gasoline-fueled engine were higher during the urban phase (Fig. 13) and entire cycle (Fig. 15) for the dynamometer road load, compared to the values obtained for the alternative dynamometer load. For the EUDC phase (Fig. 14), the relationships were reversed. For the EUDC phase, higher values of $\mathrm{NO}_{\mathrm{x}}$ emission rate with LPG fuelling were obtained for the road load (Fig. 14), while in the UDC phase (Fig. 13) and throughout the test (Fig. 15) higher emission rates $\mathrm{NO}_{\mathrm{x}}$ were obtained for the dynamometer alternative load. In the tests carried out in the papers [24], for the drag forces determined by the road method, the results of $\mathrm{CO}_{2}$ emission indices were higher than for the drag forces determined by the coefficients specified by the manufacturer. For the other pollutants, similar to the results presented in this paper, higher or lower values were obtained.

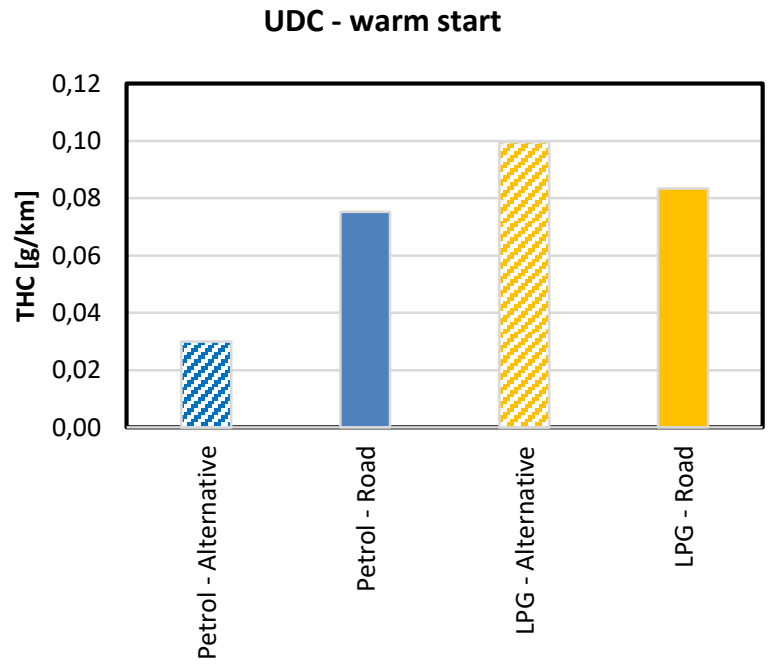

Fig. 7. Impact of resistance forces on THC emissions for UDC phase

EUDC - warm start

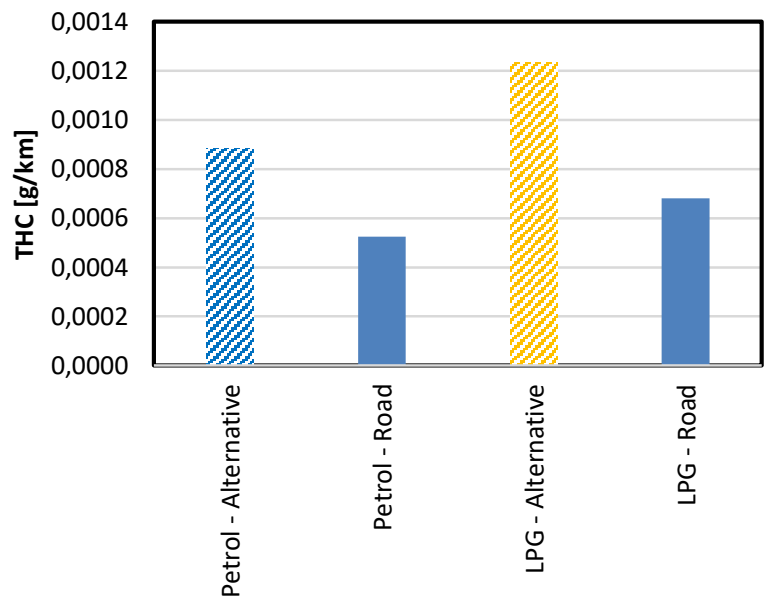

Fig. 8. Impact of resistance forces on THC emissions for EUDC phase 
NEDC - warm start

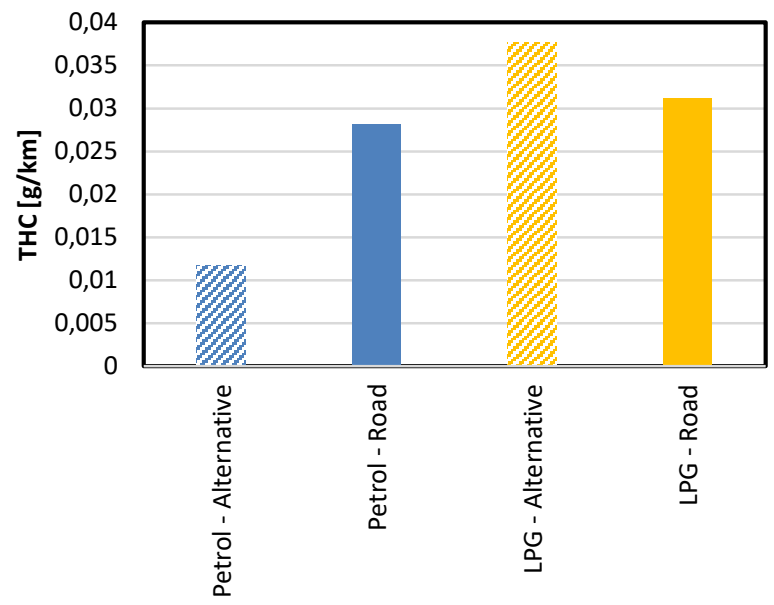

Fig. 9. Impact of resistance forces on THC emissions for NEDC test

UDC - warm start

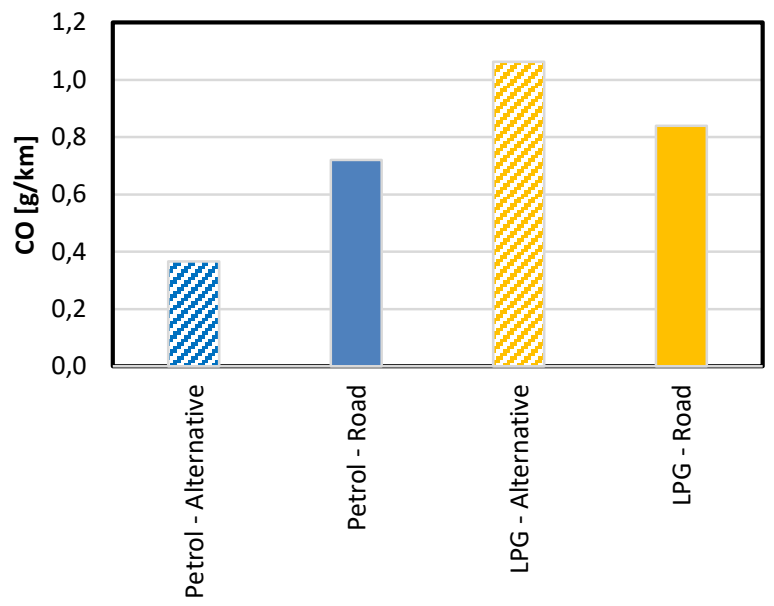

Fig. 10. Impact of resistance forces on $\mathrm{CO}$ emissions for UDC phase

EUDC - warm start

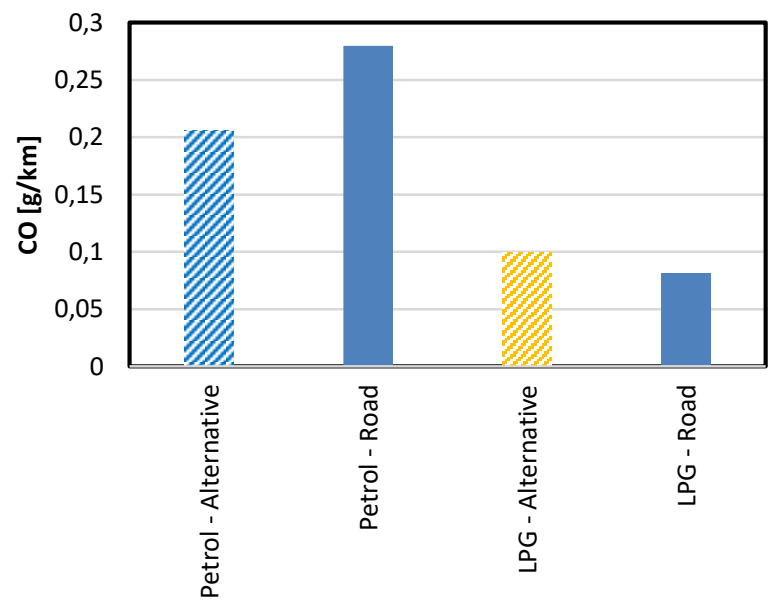

Fig. 11. Impact of resistance forces on $\mathrm{CO}$ emissions for EUDC phase
NEDC - warm start

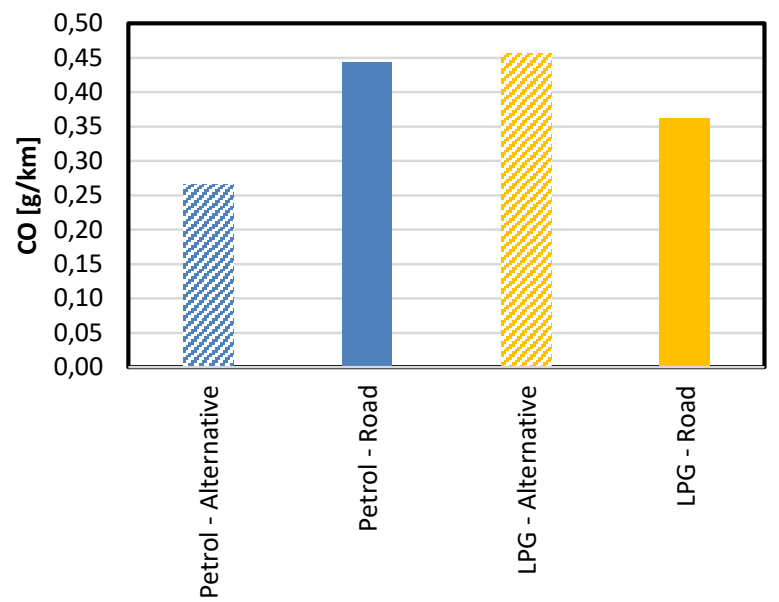

Fig. 12. Impact of resistance forces on $\mathrm{CO}$ emissions for NEDC tests

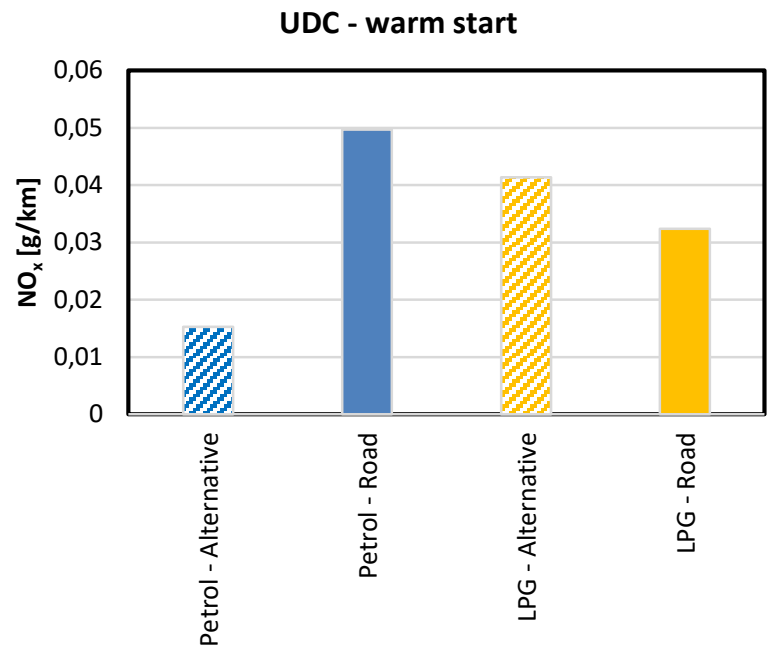

Fig. 13. Impact of resistance forces on $\mathrm{NO}_{\mathrm{x}}$ emissions for UDC phase

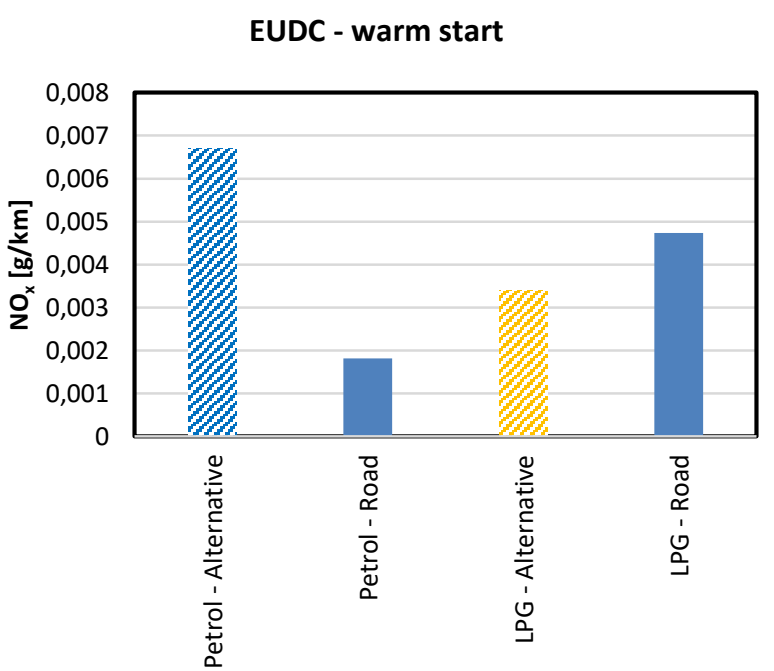

Fig. 14. Impact of resistance forces on $\mathrm{NO}_{\mathrm{x}}$ emissions for EUDC phase 


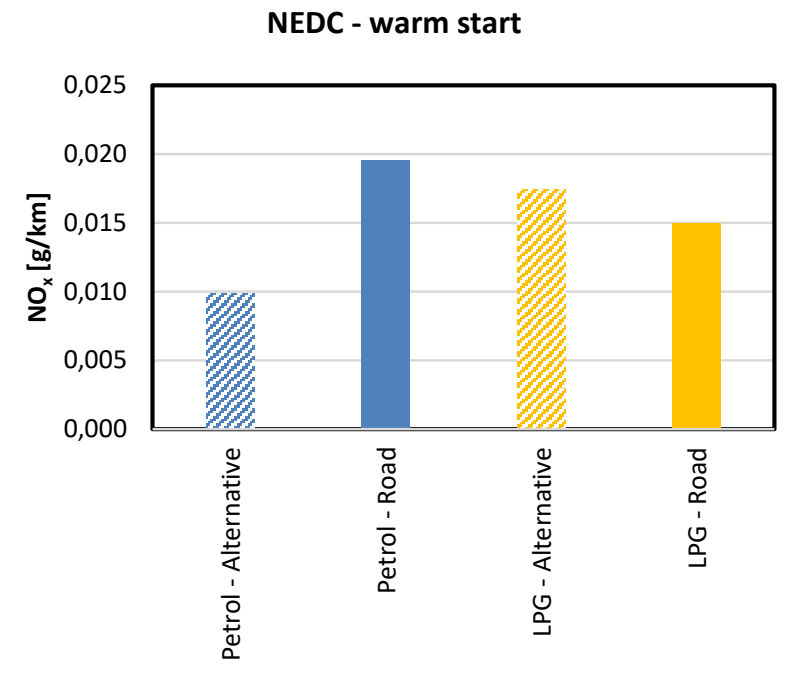

Fig. 15. Impact of resistance forces on $\mathrm{NO}_{\mathrm{x}}$ emissions for NEDC tests

Figure 16 shows a comparison of the energy consumption for the car under test, depending on the resistance-tomotion function adopted in the tests, for petrol and LPG fuels. It can be seen that, similarly to higher $\mathrm{CO}_{2}$ emission for tests with dynamometer load determined on the basis of road tests, the values of energy consumption are also higher. In comparison with the LPG fuel supply, the energy consumption for the gasoline fuel supply was higher.

Figure 17 shows the fuel economy values obtained in the tests for the analyzed car. The distance travelled per unit fuel volume is higher for petrol than for LPG. This is due to the higher energy value of one liter of gasoline in relation to one liter of LPG. However, the values of the distance travelled are lower for the dynamometer load according to the road method.

Taking into account the values of energy demand and the value of fuel consumed, the average values of engine efficiency were determined for the petrol and LPG fuels for the resistance forces analysed (Fig. 18). An increase in the efficiency of the engine operating under a higher load, for the resistance of motion determined by the road method, is clearly seen.

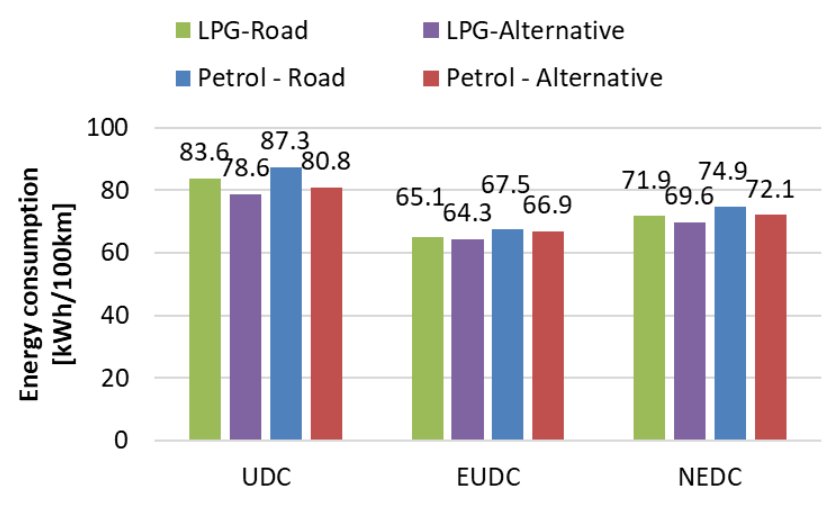

Fig. 16. Impact of resistance forces on energy consumption

In particular, an increase in engine efficiency is seen for the EUDC cycle, during which the car is moving at higher speeds and higher drag forces are acting on it. The differences in average engine efficiency values for the EUDC phase were higher by about $8-10 \%$ than for the UDC urban phase. The efficiency of the engine fueled with LPG was also marginally higher than that of the engine fueled with gasoline.

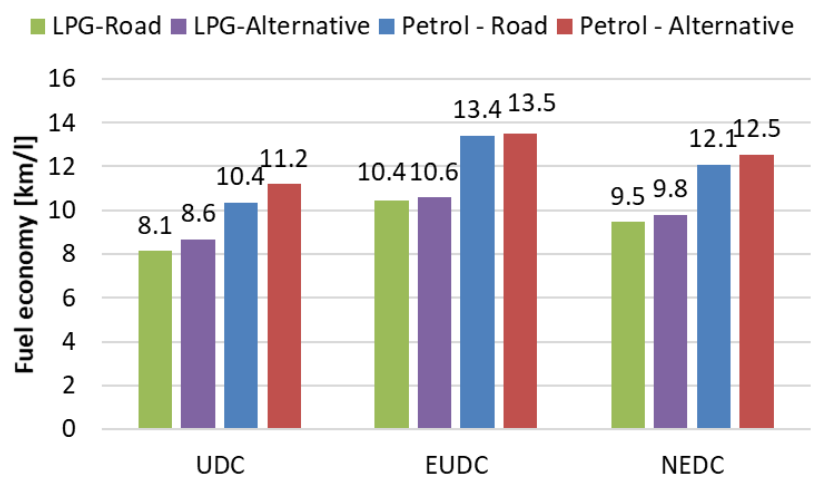

Fig. 17. Impact of resistance forces on fuel economy

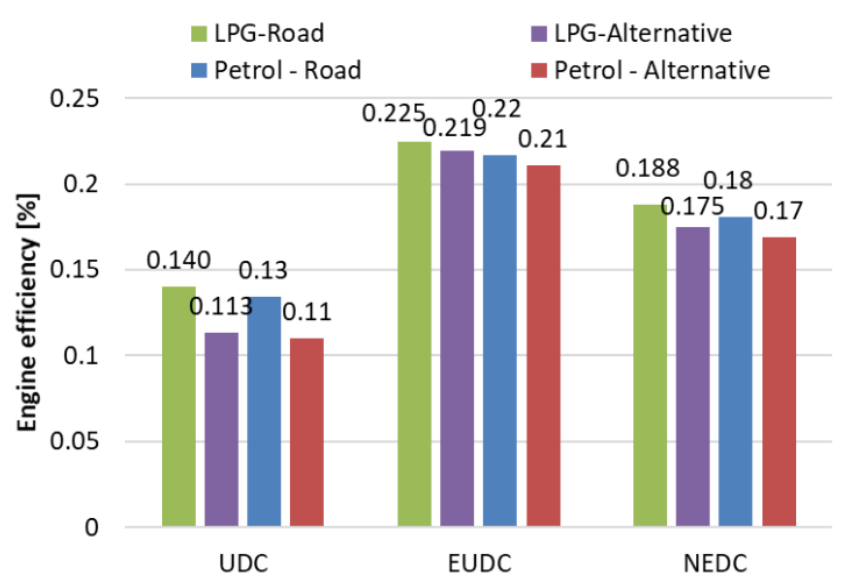

Fig. 18. Impact of resistance forces on average engine efficiency

\section{Conclusions}

The study showed that due to $\mathrm{CO}_{2}$ emissions and energy (fuel) consumption, it is important to determine the coefficients of resistance to motion on the basis of road tests. Thanks to that, the results obtained during dynamometer tests are close to the values in the real car operation conditions.

In the case of the other pollutants tested (THC, CO, $\mathrm{NO}_{\mathrm{x}}$ ), the values of the emission factors do not depend unequivocally on the traffic resistance and may be both lower and higher.

The results of the tests confirmed also the higher values of the engine efficiency at LPG fuelling in relation to petrol fuelling. Also the average engine efficiency is higher for the traffic resistance determined by the road method.

\section{Acknowledgements}

This work was supported by The Ministry of Infrastructure and Development under the Eastern Poland Development Operational Program including European Regional Development Fund, which financed the research instruments. 


\section{Nomenclature}

AT ambient temperature

$\mathrm{CO}$ carbon monoxide

$\mathrm{CO}_{2}$ carbon dioxide

CVS constant volume sampler

EUDC extra urban driving cycle

LPG liquefied petroleum gas

NEDC new European driving cycle

NMHC non-methane hydrocarbons
NOx

PEMS portable emissions measurement systems

PM particulate matter

RDE real driving emissions

SI spark ignition

THC total hydrocarbons

UDC urban driving cycle

\section{Bibliography}

[1] ANDRZEJEWSKI, M. Wpływ stylu jazdy kierowcy na zużycie paliwa i emisję substancji szkodliwych w spalinach. Praca doktorska. Wydział Maszyn Roboczych i Transportu. Politechnika Poznańska. Poznań 2013.

[2] ARCZYŃSKI, S. Mechanika ruchu samochodu. WNT. Warszawa, 1993.

[3] AVL AMA i60 Exhaust Measurement System Specification. AVL 2013.

[4] BARLOW, T.J., LATHAM, S., MCCARE, I.S. et al. A reference book of driving cycles for use in the measurement of road vehicle emissions. Project report PPR354. Transport Research Laboratory.

https://assets.publishing.service.gov.uk/government/uploads/ system/uploads/attachment_data/file/4247/ppr-354.pdf

[5] BIELACZYC, P., WOODBURN, J., SZCZOTKA, A. Exhaust emissions of gaseous and solid pollutants measured over the NEDC, FTP-75 and WLTC chassis dynamometer driving cycles. SAE Technical Paper 2016-01-1008. 2016. https://doi.org/10.4271/2016-01-1008

[6] CHARYUNG, K., HYUNWOO, L., YONGSUNG, P. et al. Study on the criteria for the determination of the road load correlation for automobiles and an analysis of key factors. Energies. 2016, 9(8), 575.

https://doi.org/10.3390/en9080575

[7] CHŁOPEK, Z., BIEDRZYCKI, J., LASOCKI, J. et al. Comparative examination of pollutant emission from an automotive internal combustion engine with the use of vehicle driving tests. Combustion Engines. 2016, 164(1), 56-64. https://doi.org/10.19206/CE-116490

[8] CUBITO, C., MILlO, F., BOCCARDO, G. et al. Impact of different driving cycles and operating conditions on $\mathrm{CO}_{2}$ emissions and energy management strategies of a Euro-6 hybrid electric vehicle. Energies. 2017, 10, 1590. https://doi.org/10.3390/en10101590

[9] DUARTE, G., GONÇALVES, G., FARIAS, T. Analysis of fuel consumption and pollutant emissions of regulated and alternative driving cycles based on real-world measurements. Transportation Research Part D: Transport and Environment. 2016, 44, 43-54.

https://doi.org/10.1016/j.trd.2016.02.009

[10] FONTARAS, G., ZACHAROF, N.-G., CIUFFO, B. Fuel consumption and $\mathrm{CO}_{2}$ emissions from passenger cars in $\mathrm{Eu}-$ rope - Laboratory versus real-world emissions. Progress in Energy and Combustion Science. 2017, 60. https://doi.org/10.1016/j.pecs.2016.12.004

[11] GOŁĘBIEWSKI, W. Relacje pomiędzy właściwościami trakcyjnymi pojazdu a zużyciem paliwa. Rozprawa doktorska. Zachodniopomorski Uniwersytet Technologiczny w Szczecinie. Wydziat Inżynierii Mechanicznej i Mechatroniki. Szczecin 2014.

[12] JAWORSKI A. Odwzorowanie oporów ruchu samochodu podczas badań emisji zanieczyszczeń w spalinach na hamowni podwoziowej. Monografia: Systemy i środki trans- portu: konstrukcja i badania: wybrane zagadnienia. Nr 21 . Oficyna Wydawnicza Politechniki Rzeszowskiej. Rzeszów 2020.

[13] JAWORSKI, A. Problematyka wyznaczania współczynników oporów ruchu samochodów do badań emisji zanieczyszczeń spalin w warunkach symulowanych na hamowni podwoziowej. Висник Національного Транспортного Університету. 2019, 3(45), 52-58, Kijów.

[14] JAWORSKI, A., BOICHENKO, S., MADZIEL, M. et al. Comparative assessment of $\mathrm{CO}_{2}$ emissions and fuel consumption in a stationary test of the passenger car running on various fuels. Наукоємні технології. 2020, 3(47). https://doi.org/10.18372/2310-5461.47.14936

[15] JAWORSKI, A., MĄDZIEL, M., KUSZEWSKI, H. et al. The impact of driving resistances on the emission of exhaust pollutants from vehicles with the spark ignition engine fuelled with petrol and LPG. SAE Technical Paper 2020-012206. 2020. https://doi.org/10.4271/2020-01-2206

[16] JAWORSKI, A., LEJDA, K., MĄDZIEL, M. Assessment of the emission of harmful car exhaust components in real traffic conditions. IOP Conferences Series: Materials Science and Engineering. 2018, 421, 042031. https://doi.org/10.1088/1757-899X/421/4/042031

[17] JAWORSKI, A., KUSZEWSKI, H., USTRZYCKI, A. et al. Analysis of the repeatability of exhaust pollutans emission research for cold and hot starts under controlled driving cycle conditions. Environmental Science and Pollution Research. 2018, 25, 17862-17877.

https://doi.org/10.1007/s11356-018-1983-5

[18] JAWORSKI, A., KUSZEWSKI, H., USTRZYCKI, A. Wyznaczanie współczynników symulacji oporów ruchu w badaniach na hamowni podwoziowej. Logistyka. 2015, 4.

[19] JAWORSKI, A., MĄDZIEL, M., LEJDA, K. Creating an emission model based on portable emission measurement system for the purpose of a roundabout. Environmental Science and Pollution Research. 2019, 26(21), 21641-21654. https://doi.org/10.1007/s11356-019-05264-1

[20] JAWORSKI, A., MĄDZIEL, M., KUSZEWSKI, H. et al. Analysis of cold start emission from light duty vehicles fueled with gasoline and LPG for selected ambient temperatures. SAE Technical Papers 2020-01-2207. 2020. https://doi.org/10.4271/2020-01-2207

[21] JIMÉNEZ, J.L., MCLINTOCK, P.M., MCRAE, G.J. et al. Vehicle specific power: a useful parameter for remote sensing and emissions studies. Ninth CRC On-Road Vehicle Emissions Workshop. San Diego, California, 04.1999. http://cires.colorado.edu/ jjose/Papers/Jimenez_VSP_9thCR C_99_final.pdf

[22] LEJDA, K., JAWORSKI, A., MĄDZIEL, M. et al. Assessment of petrol and natural gas vehicle carbon oxides emissions in the laboratory and on-road tests. Energies. 2021, 14(6), 1631. https://doi.org/10.3390/en14061631 
[23] KADIJK, G., LIGTERINK, N. Road load determination of passenger cars. 2012, Report TNO. 04.2019.

https://www.tno.nl/media/1971/road_load_determination_pa ssenger_cars_tno_r10237.pdf

[24] KÜHLWEIN, J. The impact of official versus real-world road loads on $\mathrm{CO}_{2}$ emissions and fuel consumption of European passenger cars. The International Council On A Clean Transportation. 2016.

https://www.theicct.org/sites/default/files/publications/ICCT _Coastdowns-EU_201605.pdf (accessed on 12.04.2019)

[25] MERKISZ, J., PIELECHA, J., JASIŃSKI, R. Ekologiczna ocena samochodów osobowych w drogowych testach emisyjnych. Technika Transportu Szynowego. 2015, 12.

[26] MERKISZ, J., PIELECHA, J., JASIŃSKI, R. Ocena emisji spalin pojazdów kategorii Euro $6 \mathrm{w}$ testach drogowych. Prace Naukowe Politechniki Warszawskiej. 2017, 115.

[27] MERKISZ, J., PIELECHA, J., GIS, W. Gasoline and LPG vehicle emission factors in a road test. SAE Technical Paper 2009-01-0937. 2009. https://doi.org/10.4271/2009-01-0937

[28] MERKISZ, J., PIELECHA, J., BIELACZYC, P. et al. Analysis of emission factors in RDE tests as well as in NEDC and WLTC chassis dynamometer tests. SAE Technical Paper 2016-01-0980. 2016.

https://doi.org/10.4271/2016-01-0980

[29] MERKISZ, J., PIELECHA, J., BIELACZYC, P. et al. A comparison of tailpipe gaseous emissions from the RDE an WLTP test procedures on a hybrid passenger car. SAE Technical Papers 2020-01-2217. 2020. https://doi.org/10.4271/2020-01-2217

[30] MERKISZ, J., RYMANIAK, Ł. The assessment of vehicle exhaust emissions referred to $\mathrm{CO}_{2}$ based on the investigations of city buses under actual conditions of operation. Eksploatacja i Niezawodnosc - Maintenance and Reliability. 2017, 19(4), 522-529. https://doi.org/10.17531/ein.2017.4.5

[31] MERKISZ-GURANOWSKA, A., PIELECHA, J. Emisja zanieczyszczeń z pojazdów samochodowych a parametry ruchu drogowego. Oficyna Wydawnicza Politechniki Warszawskiej. Warszawa 2014.

[32] PELKMANS, L., DEBAL, P. Comparison of on-road emissions with emissions measured on chassis dynamometer test cycles, Transportation Research Part D: Transport and Environment. 2006, 11(4), 233-241.

https://doi.org/10.1016/j.trd.2006.04.001

[33] PIELECHA, J., MERKISZ, J., KURTYKA, K. et al. Cold start emissions of passenger cars with gasoline and diesel engines in real driving emissions tests. Combustion Engines. 2019, 179(4), 160-168.

https://doi.org/10.19206/CE-2019-427

[34] Regulation No 101 of the Economic Commission for Europe of the United Nations (UN/ECE) - Uniform provisions concerning the approval of passenger cars equipped with an internal combustion engine with regard to the measurement of the emission of carbon dioxide and fuel consumption and of categories M1 and N1 vehicles equipped with an electric

Artur Jaworski, DEng. - Faculty of Mechanical Engineering and Aeronautics, Rzeszow University of Technology.

e-mail: ajaworsk@prz.edu.pl power train with regard to the measurement of electric energy consumption and range (accessed on 2.11.2020)

https://op.europa.eu/en/publication-detail//publication/12faf0c9-6266-4af2-97e4-6a67b5fbaf44

[35] Šarkan, B., Skrúcaný, T., Semanová, Š., Madleňák, R. et al. Vehicle coast-down method as a tool for calculating total resistance for the purposes of type-approval fuel consumption. Scientific Journal of Silesian University of Technology. Series Transport. 2018, 98.

https://doi.org/10.20858/sjsutst.2018.98.15

[36] Service Manual 2014 AVL- ROADSIM 48".

[37] Statistics Poland. Transport and Communication. Vehicles by Age Groups.

https://bdl.stat.gov.pl/BDL/dane/podgrup/temat/8/239/2825

[38] STOJECKI, A. Badania wpływu topografii terenu na emisję związków szkodliwych spalin samochodów osobowych. Rozprawa doktorska. Wydział Maszyn Roboczych i Transportu. Politechnika Poznańska. Poznań 2015.

[39] SYNÁK, F., RIEVAJ, V. The impact of driving resistances of a vehicle on global pollution. 17th International Scientific Conference Globalization and Its Socio-Economic Consequences. University of Zilina (accessed on 14.06.2021). https://www.researchgate.net/publication/326990879_THE_IM PACT_OF_DRIVING_RESISTANCES_OF_A_VEHICLE_O N_GLOBAL_POLLUTION

[40] SZCZOTKA, A., PUCHAŁKA, B., BIELACZYC, P. et al. Influence of the chassis dynamometer regulation on the exhaust emission results. AUTOBUSY - Technika, Eksploatacja, Systemy Transportowe. 2019, 24(6), 280-285.

https://doi.org/10.24136/atest.2019.164

[41] TIETGE, U., ZACHAROF, N., MOCK, P. et al. From laboratory to road - a 2015 update of official and "real-world" fuel consumption and $\mathrm{CO}_{2}$ values for passenger cars in Europe. International Council on Clean Transportation. 2015. https://theicct.org/sites/default/files/publications/ICCT_Lab oratoryToRoad_2015_Report_English.pdf

[42] TSIAKMAKIS, S., FONTARAS, G., CUBITO, C. et al. From NEDC to WLTP: effect on the type-approval $\mathrm{CO}_{2}$ emissions of light-duty vehicles. EUR 28724 EN. Publications Office of the European Union. Luxembourg 2017. https://doi.org/10.2760/93419

[43] UNECE. Regulamin nr 83 Europejskiej Komisji Gospodarczej Organizacji Narodów Zjednoczonych (EKG ONZ) Jednolite przepisy dotyczące homologacji pojazdów w zakresie emisji zanieczyszczeń w zależności od paliwa zasilającego silnik.

https://eur-lex.europa.eu/legalcontent/PL/TXT/PDF/?uri=CELEX:42012X0215(01)\&from=EN

[44] ZACHAROF, N., FONTARAS, G., CIUFFO, B. et al. Review of in use factors affecting the fuel consumption and $\mathrm{CO}_{2}$ emissions of passenger cars. Euro Commission. Luxembourg 2016.

https://core.ac.uk/download/pdf/81684802.pdf

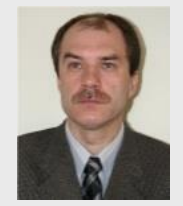

Prof. Kazimierz Lejda, DSc., DEng. - Faculty of Mechanical Engineering and Aeronautics, Rzeszow University of Technology.

e-mail:klejda@prz.edu.pl

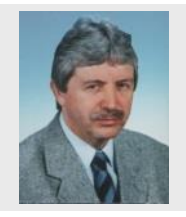

Maciej Bilski, DEng. - Faculty of Architecture, Poznan University of Technology.

e-mail:maciej.bilski@put.poznan.pl 